\title{
The National Organic Standards Training Materials: Trainer's Manual 1
}

\section{M.E. Swisher and Rose Koenig ${ }^{2}$}

This publication is only available in PDF format. The following is a brief overview of the Trainer's Guide and the links to the eight modules.

\section{Trainer Manual:}

\section{Overview of the Training Modules}

The overall purpose of these training modules is to provide agricultural service providers with enough knowledge to answer questions regarding the National Organic Standards of the USDAs National Organic Program. The development of the modules was accomplished through the contributions of individuals from the University of Florida, University of the Virgin Islands and Kentucky State University. The development of the modules and assessment of their utility as a learning tool was made possible through funding provided by the Southern Sustainable Agriculture Research and Education Program (SARE) of the USDA. Each module is designed to actively engage participants in gaining knowledge about the key concepts and important components of the regulations. The modules require participants to utilize resources that are particular to the organic regulations and developed by both the private and public sectors. It is our goal that at the end of the trainings, service providers will know the resources that are available to them and will feel comfortable using the resources and addressing the needs of their stakeholders.

The following materials are the trainer's training materials. Each trainer's module coincides with the associated participant's modules available in EDIS publication FCS8795/FY820. Trainers who conduct this training should also review the participant's materials before dispersing them to participants.

The complete training materials, which includes the trainer's and participant's manuals and associated materials such as PowerPoints and videos, are available as a for sale DVD publication Understanding the National Organic Standards: Training Materials at the University of Florida's IFAS Extension Bookstore. If you are interested in purchasing the DVD please contact the IFAS Extension Bookstore:

UF/IFAS Extension Bookstore Building 440 Mowry Road

1. This document is FCS8794, one of a series of the Family Youth and Community Sciences Department, Florida Cooperative Extension Service, Institute of Food and Agricultural Sciences, University of Florida. Original publication date April 6, 2006. Visit the EDIS Web Site at http://edis.ifas.ufl.edu.

2. M.E. Swisher, Associate Professor, Department of Family, Youth and Community Sciences and Rose Koenig, Adjuct Professor, Department of Plant Pathology, Florida Cooperative Extension Service, Institute of Food and Agricultural Sciences, University of Florida, Gainesville FL 32611.

The Institute of Food and Agricultural Sciences (IFAS) is an Equal Opportunity Institution authorized to provide research, educational information and other services only to individuals and institutions that function with non-discrimination with respect to race, creed, color, religion, age, disability, sex, sexual orientation, marital status, national origin, political opinions or affiliations. U.S. Department of Agriculture, Cooperative Extension Service, University of Florida, IFAS, Florida A. \& M. University Cooperative Extension Program, and Boards of County Commissioners Cooperating. Larry Arrington, Dean 
PO Box 110011

Gainesville, Florida 32611

Phone: 352.392 .1764

http://www.ifasbooks.ufl.edu/merchant2/

\section{How do I use the Modules?}

The modules are designed to enable anyone with minimum knowledge of the organic regulations to perform a training, as long as they review and understand the reference materials as they relate to the activities and information provided in the trainers manual. The time indicated for the activities is accurate as long as the trainer controls the extent to which participants are allowed to stray from the content of the module. Additionally, trainers should follow the instructions carefully because the modules are designed to cover the subject matter and objectives within a specific time period. Trainers should be well prepared so that they can address any questions of the participants. Many times, participants ask questions that are addressed in other modules and it is important for trainers to know the content of those modules so that they can make participants aware whether or not their question(s) will be covered.

\section{How long shall I plan for a Training?}

The modules are designed to be used as a two day training or can be used as individual modules for shorter training programs, depending on the needs of the participants. Together, they provide an excellent overview of the regulation. Individually, they address specific parts of the regulation that might be of importance to a particular group of service providers. However they are used, we have found them to be an effective learning tool.

\section{Are all of the activities required?}

Some modules have optional activities that you may or may not want to include depending on the amount of time you have and the needs of your service providers. We indicate activities as optional if they enhance the knowledge of the trainees but they should still be able to obtain the learning and application objectives without doing the optional activities.

\section{How much preparation work do I need to do before the Training?}

The majority of the preparation work is in downloading the background materials and manuals from websites and making copies of the materials for the participants. The materials can be incorporated into spiral bound workbooks or hole punched and incorporated into a three ring binder. All of this takes planning and funding. So allocate enough time and money for these activities. Additionally, the trainers need adequate time to read through the materials and understand what they need to do to in order to successfully implement the training.

\section{Modules}

Module 1: The Certification Process in Brief, http://edis.ifas.ufl.edu/pdffiles/fy/fy81901.pdf

Module 2: The Farm Plan, http://edis.ifas.ufl.edu/pdffiles/fy/fy81902.pdf

Module 3: Soil Quality and Fertility Management, http://edis.ifas.ufl.edu/pdffiles/fy/fy81903.pdf

Module 4: Seeds, Annual Transplants and Plant Stock, http://edis.ifas.ufl.edu/pdffiles/fy/fy81904.pdf

Module 5: Crop Pest, Weed \& Disease Management, http://edis.ifas.ufl.edu/pdffiles/fy/fy81905.pdf

Module 6: Maintaining Organic Integrity, http://edis.ifas.ufl.edu/pdffiles/fy/fy81906.pdf

Module 7: Handling and Processing, http://edis.ifas.ufl.edu/pdffiles/fy/fy81907.pdf

Module 8: Livestock, http://edis.ifas.ufl.edu/pdffiles/fy/fy81908.pdf

\section{Contributing Authors}

Rose Koenig, Courtesy Assistant Professor, Department of Plant Pathology, and CoDirector Center for Organic Agriculture, University of Florida. Modules 1-8. 
George Kuepper, Program Specialist, The National Center for Appropriate Technology. Modules 6,8.

Elizabeth Lamb, Coordinator of Integrated Pest Management for Ornamentals, New York State IPM Program, Cornell University. Module 1.

Gene McAvoy, Regional Vegetable Extension Agent III, Hendry County Extension, University of Florida. Module 3.

Juan Carlos Rodriguez, Director for Education and Outreach, Florida Organic Growers. Modules $2-6$.

Kendall Sanderson, Environmental Scientist, Tampa Bay Watch, Inc. Modules 1-7.

Mital Shah, Graduate Research Assistant, School of Natural Resources and Environment, University of Florida. Modules 1,2,4,5,6,8.

M.E. Swisher, Associate Professor, Department of Family, Youth and Community Sciences, and Director Center for Organic Agriculture, University of Florida. Modules 1-8.

Alicia Whidden, Extension Agent II, Sarasota County Extension, University of Florida. Module 5. 